\title{
IMPLEMENTASI METODE WEB ENGINEERING DALAM MEMBANGUN SISTEM E-RESERVATION PEMESANAN KAMAR HOTEL
}

\author{
Helda Yudiastuti ${ }^{1}$, Irwansyah ${ }^{2}$ \\ Dosen Universitas Bina Darma ${ }^{1}$ \\ Jalan Jenderal Ahmad Yani No.3 Palembang \\ Sur-el : helda.yudiastuti@binadarma.ac.id ${ }^{1}$, irwansyah@binadarma.ac.id ${ }^{2}$
}

\begin{abstract}
This research was conducted at Hotel Telaga Biru Pagaralam, aims to create a new system that can overcome the problems that occur in the Hotel, especially in terms of booking rooms. The current room booking system is still done manually, which is still recorded in the book when guests check in until check out, then it is given a receipt as proof of payment in advance to the guest according to the length of the guest staying. In addition to coming directly customers can book a room by contacting the hotel by phone. For this, researchers are doing the action of making a system engineering information-based hotel reservation with the system development strategy using the Web engineering method, the tools used in the design are Unified Modelling Language (UML), in the development of this application authors use the PHP and MySql programming language as the Database of room booking systems. This system generates a system that allows customers and hotel to make bookings.
\end{abstract}

Keywords: Reservation, hotel, E-Reservation, web engineering

\begin{abstract}
Abstrak : Penelitian ini dilakukan pada Hotel Telaga Biru Pagaralam, bertujuan untuk membuat sebuah sistem baru yang dapat mengatasi permasalahan yang terjadi dihotel, khususnya dalam hal pemesanan kamar. Sistem pemesanan kamar saat ini masih dilakukan secara manual yaitu masih dicatat dibuku saat tamu melakukan check in sampai check out, kemudian diberikan kwitansi sebagai bukti bayar dimuka kepada tamu sesuai lama tamu itu menginap. Selain datang langsung pelanggan dapat memesan kamar dengan menghubungi pihak hotel melalui telepon. untuk itulah peneliti melakukan tindakan membuat sebuah rekayasa sistem informasi pemesanan hotel berbasis web dengan strategi pengembangan sistem menggunakan metode Web engineering, tools yang digunakan dalam perancangan adalah Unified Modelling Language (UML), dalam pengembangan aplikasi ini penulis menggunakan bahasa pemrograman PHP dan MySql sebagai Database sistem pemesanan kamar. Sistem ini menghasilkan sebuah sistem yang memudahkan pelanggan dan pihak hotel dalam melakukan pemesanan kamar.
\end{abstract}

Kata kunci: Pemesanan, hotel, E-Reservation, web engineering

\section{PENDAHULUAN}

Hotel adalah tempat yang sangat mengutamakan kenyamanan dan keramahan staff hotelnya[1]. Kualitas suatu layanan sangat menentukan keuntungan ekonomi dan juga keuntungan kompetitif bagi pihak hotel [2]. Reservasi adalah sebuah proses klerikal elektronik dimana produk perjalanan seperti tiket pesawat, kamar hotel, kamar pada kapal pesiar tersedia untuk dipakai dan pada akhirnya dibeli oleh individu [3]. Hotel Telaga Biru Pagaralam merupakan penginapan yang menawarkan kepada calon pelanggannya, untuk menginap dengan kenyamanan yang diberikan oleh Hotel Telaga Biru Pagaralam. Pada saat ini Hotel Telaga Biru Pagaralam dalam pengolahan data masih manual yaitu masih berdasarkan pencatatan pada buku setiap tamu yang akan melakukan check in sampai check out, misalnya ketika seorang tamu akan check in, resepsionis 
akan meminta kartu identitas tamu berupa kartu tanda penduduk, surat izin mengemudi, dan lainlain. Kemudian datanya akan dicatat ke dalam buku check in, pada buku check in ini, pencatan lama tamu akan menginap disesuaikan dengan kebutuhan tamu tersebut. Setelah proses check in selesai, akan dicatat pada buku dan diberikan kwitansi sebagai bukti bayar dimuka kepada tamu yang terhitung sesuai lama tamu itu menginap. jika tamu tersebut melewati batas waktu check out, maka akan dibuat kembali kwitansi baru. Selain itu juga pelanggan yang ingin memesan kamar dapat menghubungi pihak Hotel Telaga Biru Pagaralam lewat telepon atau datang langsung kemudian data pelanggan tersebut akan dicatat kedalam buku pemesanan, sementara komputer digunakan sebagai alat pembuatan surat laporan saja dengan menggunakan Microsoft Excel dan Microsoft Word. Upaya ini membuat suatu perubahan dibidang pengolahan data tamu dan pemesanan kamar, tidak hanya mengandalkan kemampuan manual, tetapi lebih berorientasi pada efisiensi dan otomatisasi serta transparansi proses data, untuk mengatasi beberapa permasalahan diatas peneliti membangun sebuah sistem e-reservation kamar yang nantinya dapat memudahkan pelanggan dalam memesan kamar, dan juga memudahkan pihak hotel khususnya bagian administrasi dalam mendata tamu yang akan menginap. Penelitian ini bertujuan untuk membangun sebuah sistem reservasi dengan mengadopsi teknologi informasi.

Metode pengembangan sistem yang digunakan pada penelitian ini adalah web engineering, yang terdiri dari beberapa tahapan yaitu communication, Planning, Modeling, Construtions, dan Deployment [4].

Hardian Jungjungan Sitanggang, Elis Hernawati, Ferra Arik Tridalestari (2017) membuat penelitian tentang sistem reservasi kamar wisma [5]. Pada penelitian ini menghasilkan aplikasi pemesanan kamar wisma yang bisa dipesan secara online oleh tamu wisma. Selain pemesanan online, aplikasi juga menyediakan pemesanan langsung (onsite).

Penelitian lainnya adalah penelitian yang di lakukan oleh Samuel Eddy Gio Tatu, Andree E. Widjaja, dan Suryasari (2019), penelitian ini menghasilkan sebuah sistem manajemen dan reservasi yang menunjukkan bahwa tingkat efektifitas, efisiensi serta transparansi meningkat karena tamu dimudahkan dalam melakukan pemesanan kamar mulai dari proses pengecekan kamar sampai dengan proses pembayaran [6].

\section{METODOLOGI PENELITIAN}

\subsection{Metode Pengumpulan Data}

Adapun metode pengumpulan data yang penulis gunakan dalam penelitian ini adalah wawancara, Observasi, dan studi pustaka. Wawancara dilakukan dengan pihak hotel, halhal yang didiksusikan berkaitan dengan reservasi hotel, observasi merupakan sesuatu yang dilakukan dengan cara mengamati pekerjaan yang dilakukan dalam hal pemesanan kamar, sedangkan studi pustaka dilakukan dengan cara mencari lireratur-literatur dan teori-teori yang berkaitan dengan penelitian. 


\subsection{Metode Pengembangan Sistem}

Metode pengembangan sistem yang digunakan pada penelitian ini adalah model rekayasa web (Web Engineering). Metode ini terdiri dari Communication, Planning, Modeling, Constructions, dan Deployment [4]. Adapun tahapannya dapat dilihat pada gambar 1 .

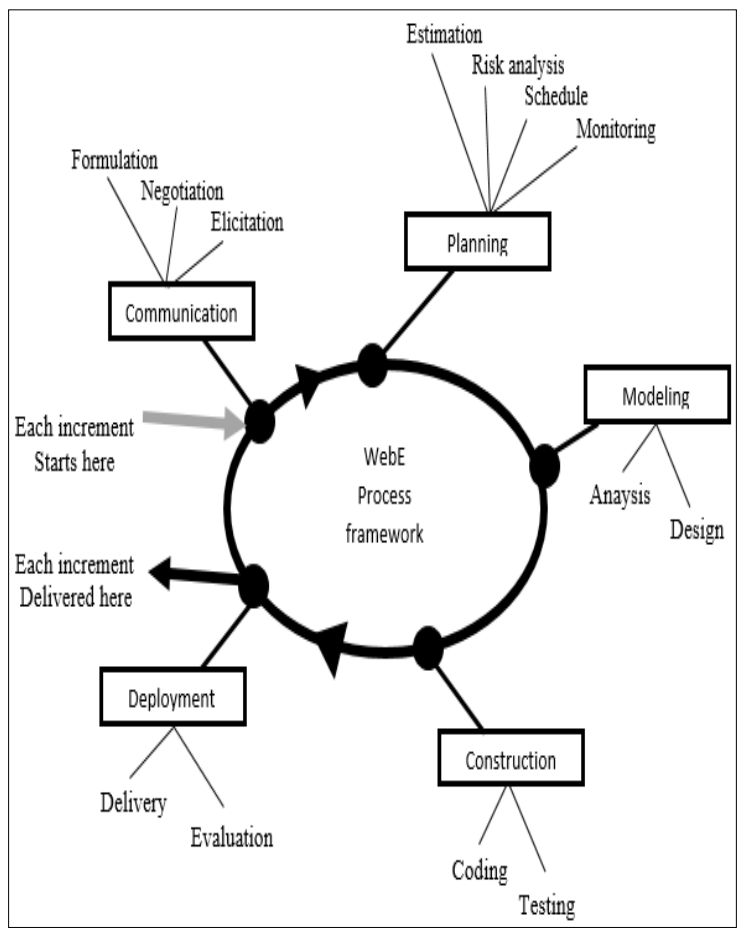

Gambar 1. Metode Web Engineering

\section{HASIL DAN PEMBAHASAN}

\subsection{Communication (Komunikasi)}

Pada tahapan ini terdiri dari tiga fase, yaitu Formulation, negociation, dan elicititation. Pada fase formulation peneliti menentukan tujuan, kebutuhan dan siapa yang akan menggunakan sistemini, tujuan dari pembuatan sistem adalah untuk dapat menghasilkan perangkat lunak pemesanan kamar secara online tanpa harus datang terlebih dahulu serta dapat menambah jumlah pengunjung, selain itu kebutuhan sistem adalah untuk dapat mempromosikan Hotel Telaga Biru secara lebih luas, karena sistem yang dihasilkan bersifat online. Pengguna yang menggunakan sistem ini adalah tamu dan admin.

Fase kedua yaitu negociation. Fase ini merupakan tahap negosiasi antara pengembang sistem dengan pengguna atau orang yang menggunakan sistem yang akan dibuat. Tahap ini sudah dilakukan dengan cara wawancara langsung dengan pegawai dan pemilik hotel Telaga Biru.

Fase ketiga yaitu elicitation. Fase ini merupakan tahap untuk menggambarkan permasalahan yang terjadi melalui pengumpulan data. Pengumpulan data dilakukan dengan beberapa cara diantaranya yaitu dengan wawancara, dan observasi. Data-data yang telah dikumpulkan yaitu data profil perusahaan, data kamar, dan data harga kamar. Berdasarkan data-data tersebut, maka didapat beberapa masalah yang terjadi, yaitu data tamu masih dicatat di buku, lambatnya dalam pencarian data kamar, pembuatan laporan pengunjung masih dilakukan dengan manual dengan mencatat kwitansikwitansi pemesanan kamar. Sehingga pegawai kesulitan untuk mendata berapa jumlah pengujung yang datang dalam mingguan, bulanan ataupun tahunan.

\subsection{Planning (Perencanaan)}

Tahap perencanaan terdiri dari beberapa tahapan, pertama adalah tahap estimasi yang terdiri dari waktu, biaya dan sumber daya manusia. Semua tahapan sudah dilakukan estimasinya. Kedua adalah tahap analisis resiko, mulai dari orang, produk, dan proses. Tahap ini sudah dilakukan analisisnya. Ketiga adalah tahap penjadwalan. Penelitian ini sudah dilakukan sesuai dengan jadwal yang telah direncanakan. 


\subsection{Modelling (Pemodelan)}

\subsubsection{Use Case Diagram}

Tahap pemodelan merupakan tahapan perancangan sistem. Salah satu alat bantu yang digunakan dalam penelitian ini adalah dengan membuat diagram UML yang terdiri dari use case diagram, use case diagram merupakan alat perancangan yang digunakan untuk mengetahui apa yang digunakan pengguna yang disebut sebagai aktor. Sedangkan apa yang dilakukan oleh aktor terhadap sistem disebut sebagai use case. Use Case atau Diagram Use Case merupakan pemodelan untuk melakukan (behavior) sistem informasi yang akan dibuat [7].

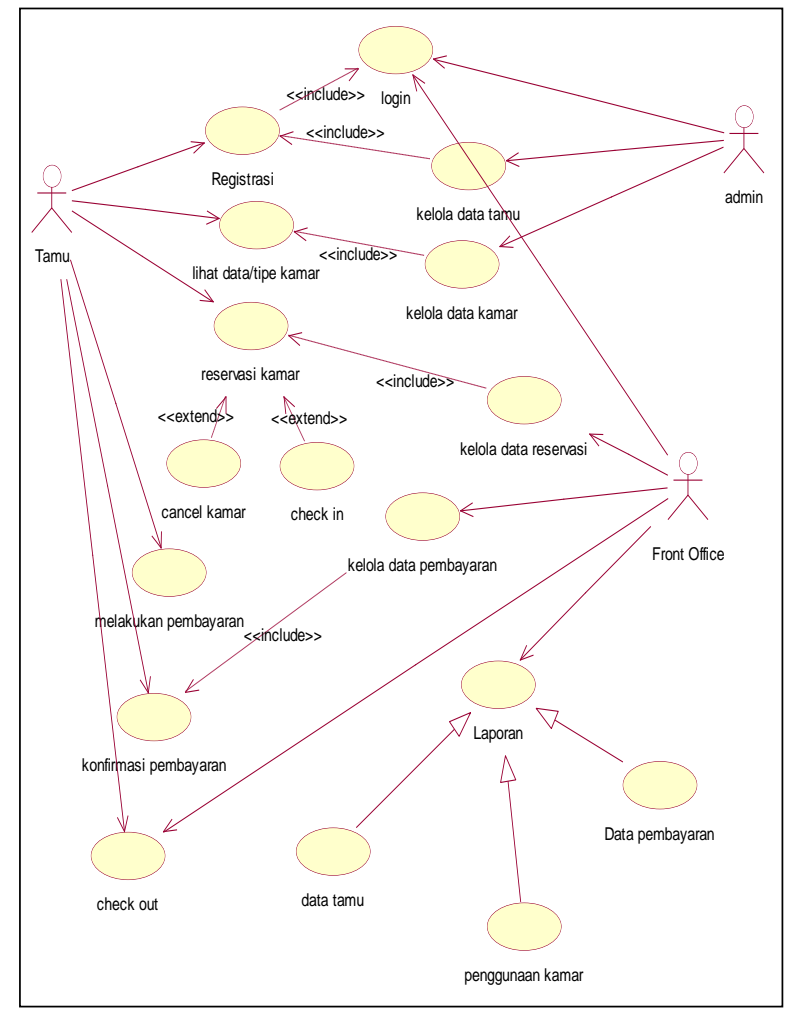

Gambar 2. Use case Diagram

Gambar 2 diatas ini merupakan implementasi dari penggambaran diagram use case pada sistem e-reservation pemesanan kamar. Diagram use case terdiri dari beberapa aktor dan use case. Aktor merupakan orang yang menggunakan sistem. Aktor dalam penelitian ini terdiri dari 3 aktor yaitu tamu, front office dan admin. Sedangkan use case merupakan apa yang dilakukan oleh aktor terhadap sistem ereservation ini.

Aktor tamu, mereka dapat melihat data kamar, melakukan reservasi kamar dengan terlebih dahulu melakukan registrasi. Tamu yang belum registrasi tidak dapat memesan kamar mereka hanya dapat melihat-lihat data kamar saja. aktor admin hanya mengelola data kamar dan data user. Front office mengelola data reservasi, data pembayaran dan membuat laporan, yang terdiri dari laporan data tamu, laporan data penggunaan kamar dan laporan data pembayaran.

\subsubsection{Activity Diagram}

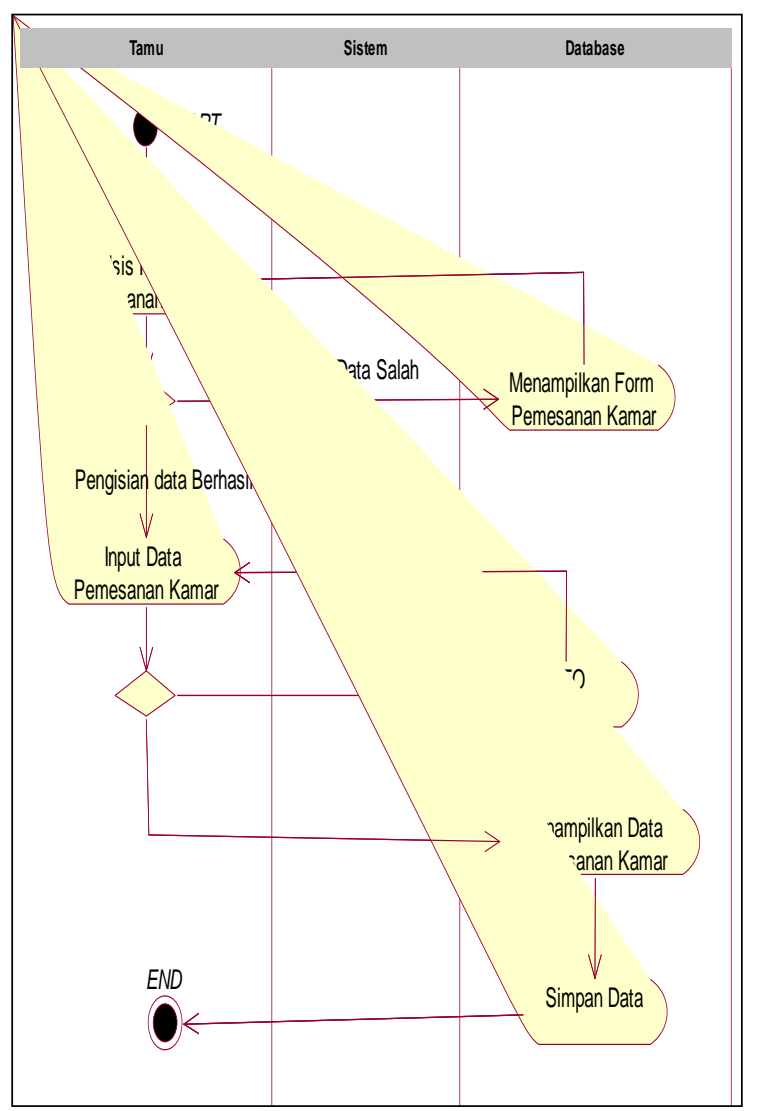

Gambar 3. Activity diagram pemesanan 


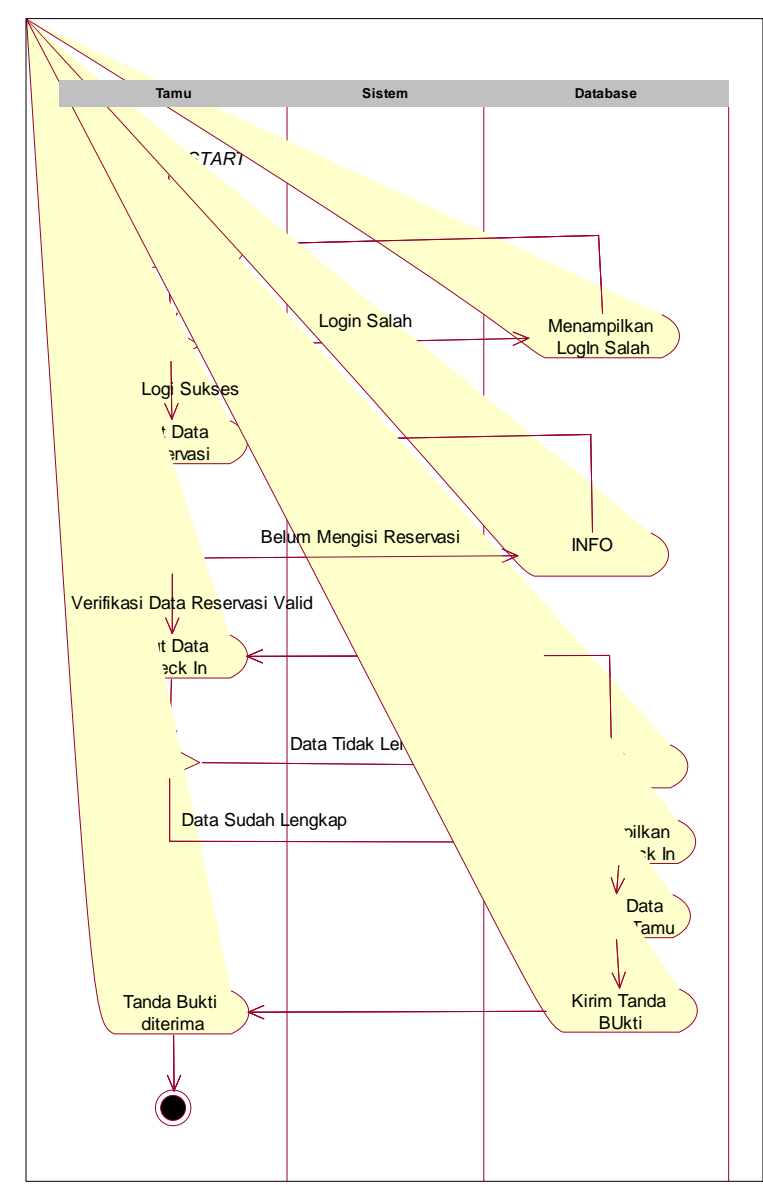

Gambar 4. Activity diagram check In

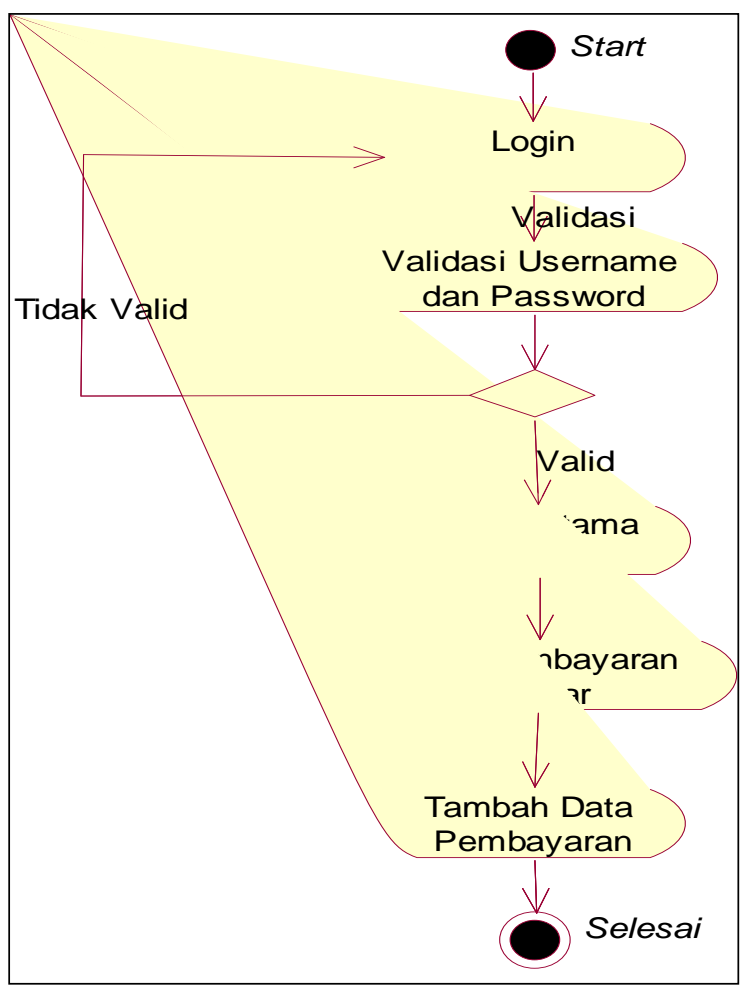

Gambar 3, 4, dan 5 menunujukkan pemodelan berikutnya yaitu dengan membuat activity diagram. Activity Diagram merupakan urutan penggambaran Sistem E-Reservation berdasarkan aktor. Apabila use case diagram menggambarkan apa yang dilakukan oleh aktor, activity diagram menggambarkan kegiatan apa yang akan dilakukan oleh aktor didalam sistem yang akan dibuat.

Pemodelan berikutnya adalah dengan membuat rancangan tabel database yang terdiri dari beberapa tabel yaitu, tabel tamu, tabel reservasi, tabel pembayaran, tabel kamar, dan tabel Front Office. Selanjutnya setelah merancang tabel database, peneliti menggambarkan perancangan user interface antara aplikasi yang dibuat dengan pengguna sistem e-Reservation ini. Perancangan user interface ini dimulai dari registrasi tamu untuk dapat memesan kamar, sampai dengan tamu melakukan pembayaran.

\subsection{Constructions}

Fase ini merupakan tahap untuk membangun sistem e-reservation pemesanan kamar hotel. Sistem dibangun dengan menggunakan bahasa PHP dan Mysql sebagai database. Untuk mengakses sistem ini ada beberapa pengguna yang dpat melakukannya, yaitu tamu (orng yang akan menginap di Hotel Telaga Biru), Admin (Orang yang mengelola data sistem e-reservation secara keseluruhan), Front Office (orang yang mengelola transaksi di sistem $e$ reservation).

Menjalankan Sistem e-reservation pemesanan kamar Hotel Telaga Biru Pagaralam ini secara langsung harus mempunyai server web local yaitu apache, Web ini mempunyai halaman utama atau halaman depan yaitu halaman index

Gambar 5. Aktivity Diagram Pembayaran 
yang berfungsi sebagai halaman utama secara otomatis pada saat web ini diakses.

Langka pertama untuk mengaktifkan halaman utama terlebih dahulu kita membuka Internet Explorer untuk mengaktifkan halaman utama. Setelah Internet Explorer diaktifkan maka kita masukan alamat halaman utama di kotak address yang terdapat di Internet Explorer.

Hasil dari pembuatan website ini adalah halaman-halaman informasi yang nantinya dijalankan dengan menggunakan browser. Adapun website ini memiliki sub-sub menu sebagai berikut :

1. Menu Home merupakan link ke menu dari web pendataan pemesanan kamar pada Hotel Telaga Biru Pagaralam.

2. Menu profil merupakan link ke menu profil yang berfungsi untuk informasi halaman Hotel Telaga Biru Pagaralam.

3. Menu registrasi tamu merupakan link ke registrasi tamu pada web yang berfungsi untuk pendaftaran tamu.

4. Menu pesan kamar merupakan link ke pesan kamar pada web yang berfungsi untuk pemesanan kamar untuk tamu.

5. Counter, merupakan pendataan untuk mengetahui jumlah yang membukan web pada Hotel Telaga Biru Pagaralam.

6. Kalender, merupakan pendataan tanggal jam user pada web Hotel Telaga Biru Pagaralam.

Setelah alamat halaman utama diaktifkan maka pemakai (user) dapat mengakses halamanhalaman yang terdapat di dalam halaman utama seperti halaman

\section{Halaman Home}

Halaman home merupakan rancangan pertama untuk website dan pemesanan kamar dengan menggunakan PHP pada Hotel Telaga Biru Pagaralam yang terdiri link home, link profil, link kamar, link registrasi tamu dan link khusus admin. Terdapat juga fasilitas yang lain seperti login untuk tamu, jam, kalender, counter dan daftar links.

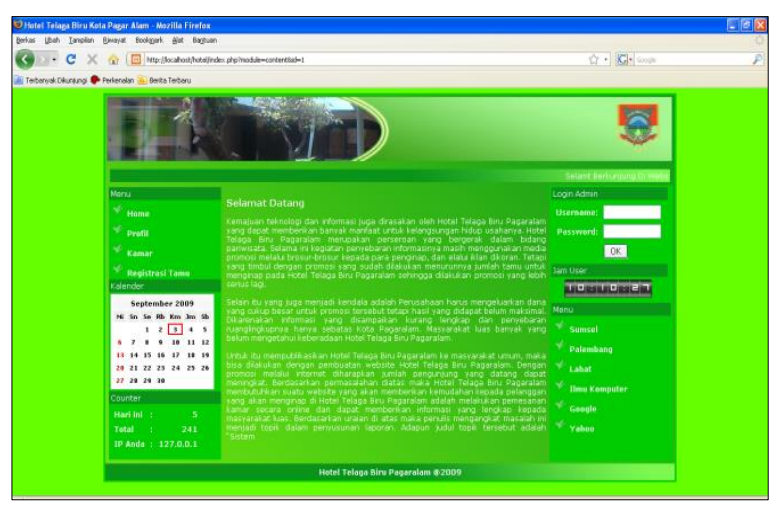

\section{Gambar 6. Halaman Home}

Pada layar teratas terdapat nama HOTEL TELAGA BIRU PAGARALAM dan nama dibawahnya terdapat menu home, profil, kamar, registrasi tamu, pesan kamar dan khusus login, terdapat juga logo yang di animasi dari animasi flash, adapun isi menu terdapat pilihan, yaitu:

a. Link Home, berfungsi menampilkan tampilan utama dari situs Hotel Telaga Biru Pagaralam yang berisi kamar.

b. Link Profil, berfungsi menampilkan informasi tentang profil Hotel Telaga Biru Pagaralam.

c. Link Kamar, berfungsi untuk halaman informasi kamar pada Hotel Telaga Biru Pagaralam.

d. Link Registrasi Tamu, berfungsi untuk halaman registrasi tamu yang baru pad Hotel Telaga Biru Pagaralam. 
e. Kalender, berfungsi menampilkan informasi tanggal yang ada pada web.

f. Counter, berfungsi untuk menampilkan informasi jumlah pengujung yang membuka website. Cari, berfungsi untuk mencari berita yang ada di website.

g. Jam, Berfungsi untuk menampilkan informasi jam user.

h. Counter, berfungsi untuk menampilkan informasi tentang jumlah pengunjung.

\section{Halaman Profil}

Jika diklik link profil maka akan menampilkan sekilas tentang profil, bentuk tampilannya seperti gambar dibawah ini, yang isinya terdapat link halaman home, link halaman profil, link kamar, link registrasi tamu, link pesan kamar dan link halaman khusus admin. Selain link terdapat juga kalender, counter, jam digital, gambar, daftar link dan login.

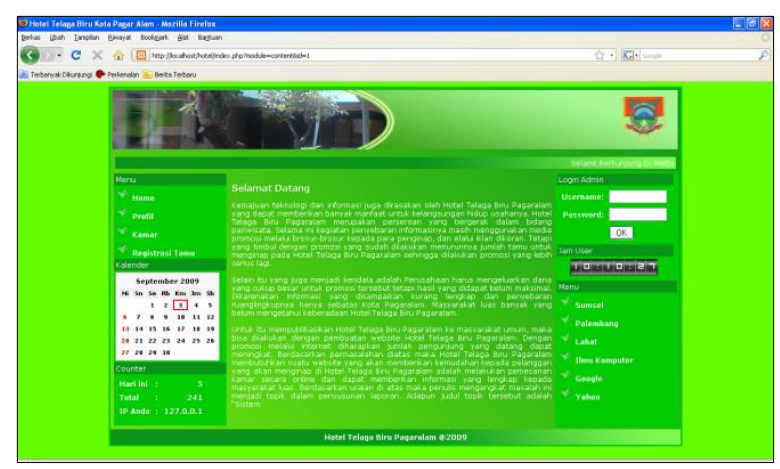

Gambar 7. Halaman Profil

\section{Halaman Kamar}

Jika diklik link kamar maka akan menampilkan halaman kamar pada Hotel Telaga Biru Pagaralam, bentuk tampilannya seperti gambar dibawah ini, yang isinya link halaman home, link halaman profil, link kamar, link registrasi tamu, link pesan kamar dan link halaman khusus admin. Selain link terdapat juga kalender, counter, jam digital, gambar, daftar link dan login.

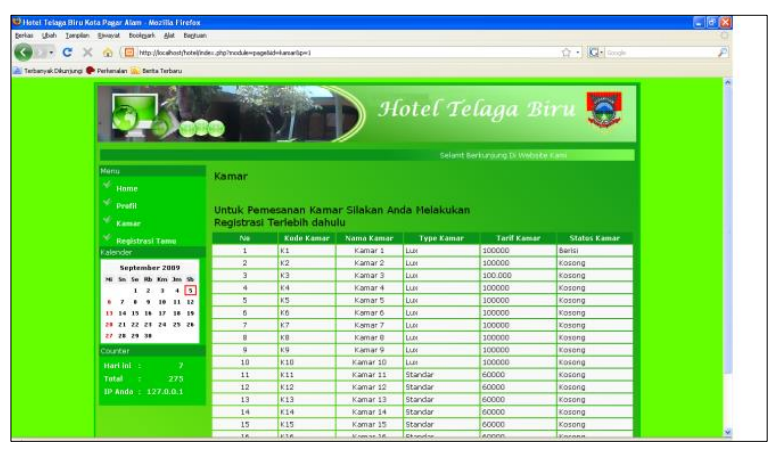

Gambar 8. Halaman Kamar

\section{Halaman Registrasi Tamu}

Jika diklik link registrasi tamu maka akan menampilkan halaman tamu tamu pada Hotel Telaga Biru Pagaralam, bentuk tampilnya seperti gambar dibawah ini, yang isinya terdapat link halaman home, link halaman profil, link kamar, link registrasi tamu, link pesan kamar dan link halaman khusus admin. Selain link terdapat juga kalender, counter, jam digital, gambar, daftar link dan login.

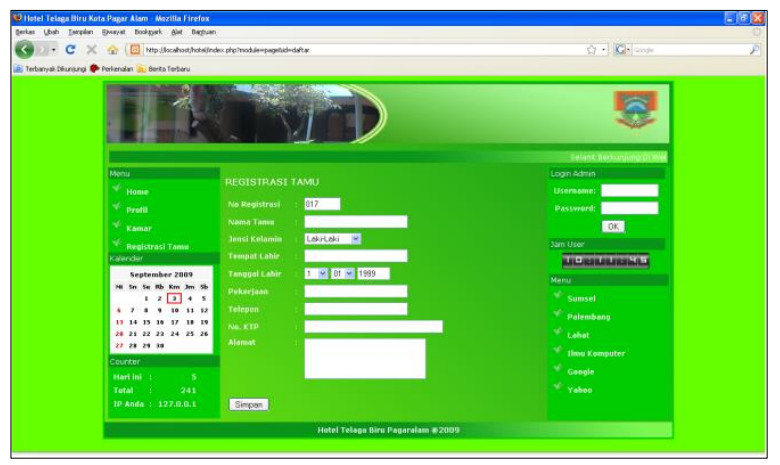

Gambar 9. Halaman Registrasi Tamu

\section{Halaman Pemesanan}

Jika diklik link pesan kamar maka akan menampilkan halaman pesan kamar pada Hotel Telaga Biru Pagaralam, bentuk tampilan seperti gambar dibawah ini, yang isinya terdapat link 
halaman home, link halaman profil, link kamar, link registrasi tamu, link pesan kamar dan link halaman khusus admin. Selain link terdapat juga kalender, counter, jam digital, gambar, daftar link dan login.

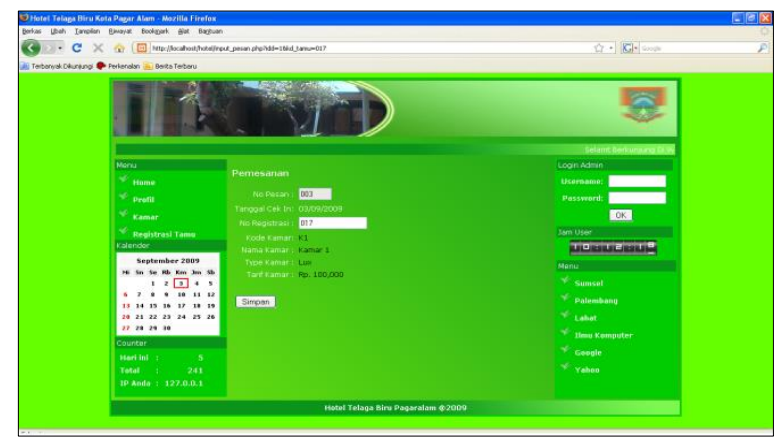

Gambar 10. Halaman Pesan Kamar

\section{Halaman Admin Tamu}

Jika diklik link tamu maka akan menampilkan data untuk melihat data tamu, bentuk tampilannya seperti gambar dibawah yang isinya yaitu link content, link tamu, link kamar, link pemesanan, link laporan, link Ubah Login, link ubah login dan logout.

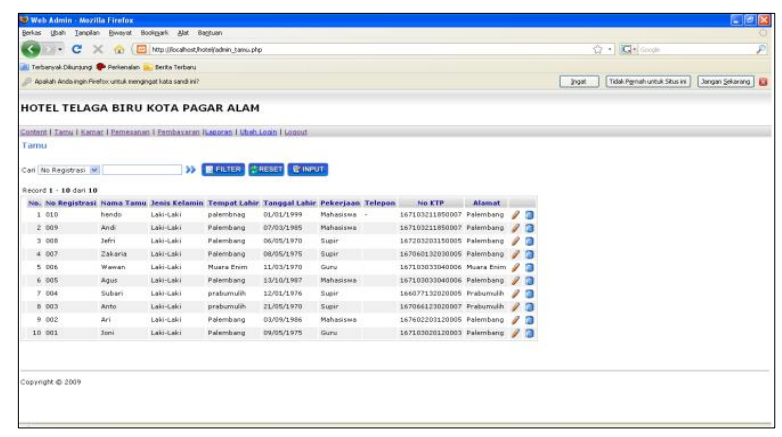

Gambar 11. Halaman Admin Tamu

\section{Halaman Admin Kamar}

Jika diklik link kamar maka akan menampilkan data untuk melihat data kamar, bentuk tampilannya seperti gambar dibawah yang isinya yaitu link content, link tamu, link kamar,link pemesanan, link laporan, link Ubah Login, link ubah login dan logout.

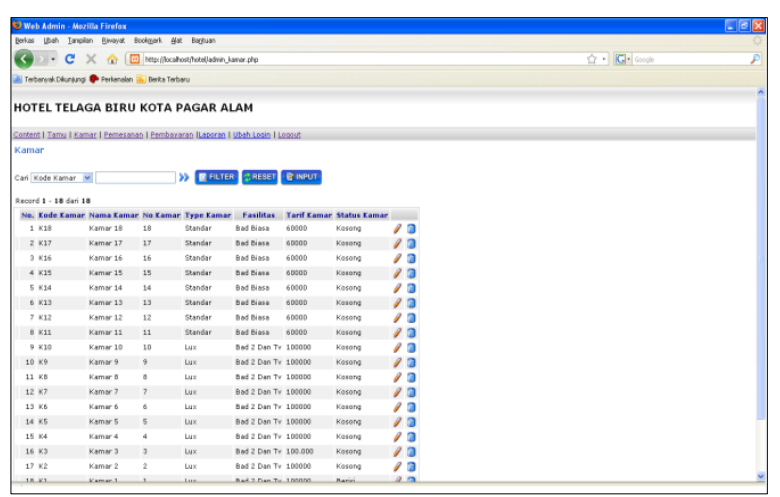

Gambar 12. Halaman Admin Kamar

\section{Halaman Admin Pemesanan}

Jika diklik link pemesanan maka akan menampilkan data untuk melihat data pemesanan, bentuk tampilannya seperti gambar dibawah yang isinya yaitu link content, link tamu, link pemesanan, link laporan, link Ubah Login, link ubah login dan logout.

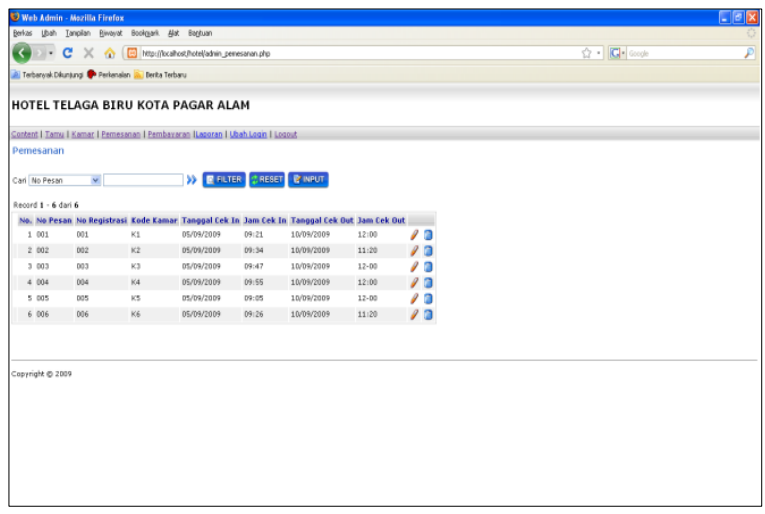

Gambar 13. Halaman Admin Pemesanan

\section{Halaman Admin Pembayaran}

Jika diklik link pembayaran maka akan menampilkan data untuk melihat data pembayaran, bentuk tampilannya seperti gambar dibawah yang isinya yaitu link content, link tamu, link pemesanan, link pembayaran, link laporan, link Ubah Login, link ubah login dan logout. 


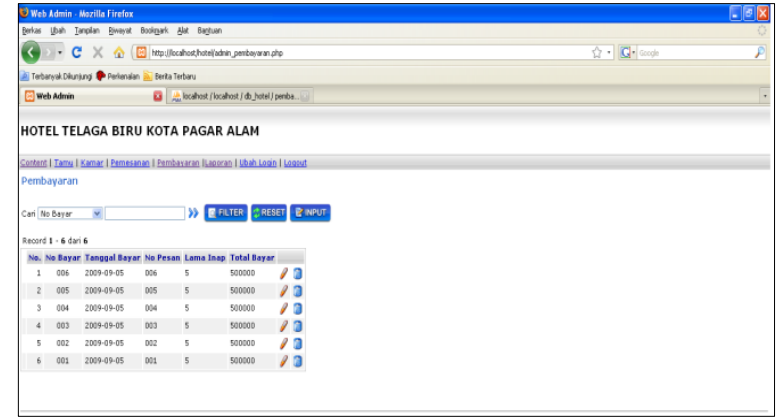

Gambar 14. Halaman Admin Pembayaran

\section{Halaman Laporan}

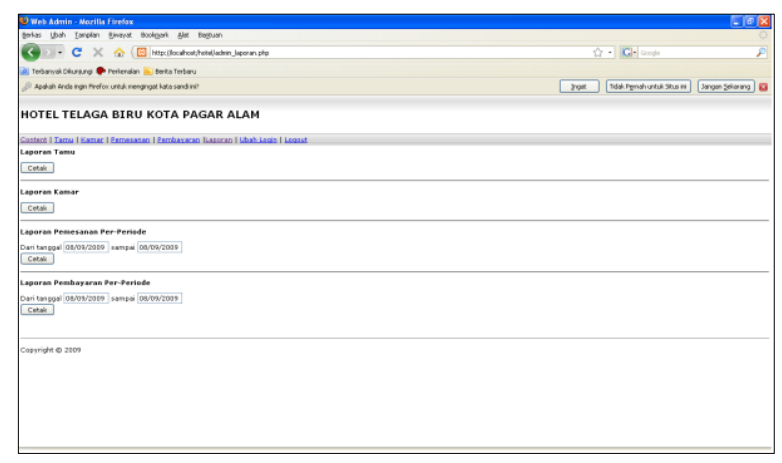

Gambar 15. Halaman Laporan

\section{Halaman Laporan Tamu}

Halaman laporan tamu merupakan informasi tentang data tamu pada Hotel Telaga Biru Kota Pagaralam.

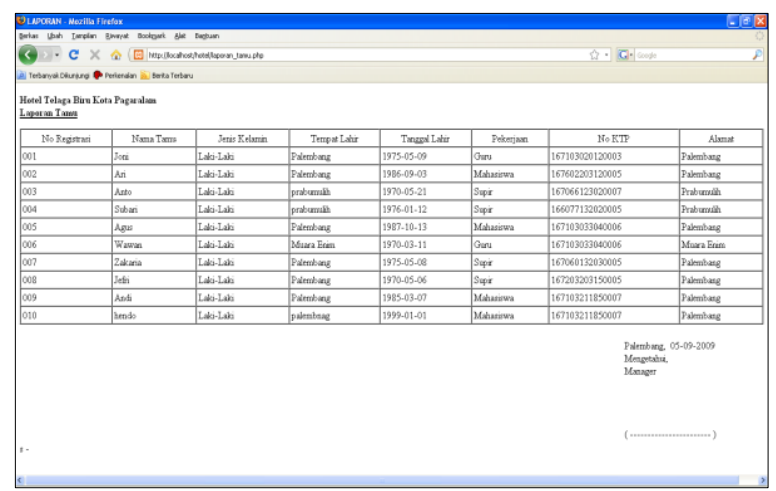

Gambar 16. Halaman Laporan Tamu

\section{Halaman Laporan Kamar}

Halaman laporan kamar merupakan informasi tentang data kamar pada Hotel Telaga Biru Kota Pagaralam.

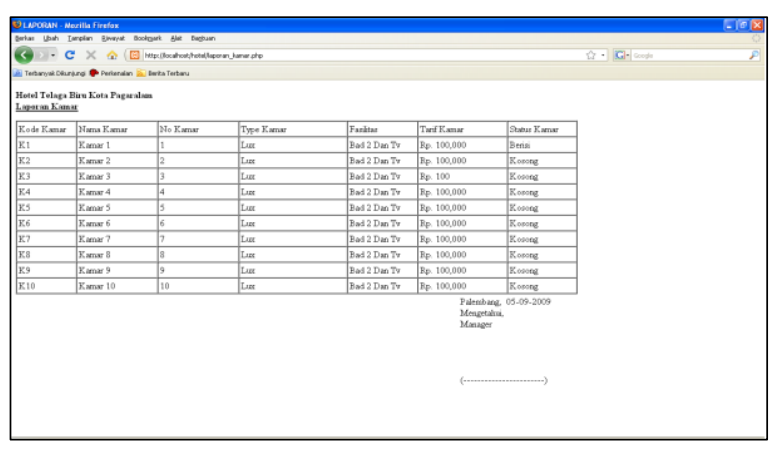

\section{Gambar 17. Halaman Laporan Kamar}

\section{Halaman Laporan Pemesanan Perperiode}

Halaman laporan pemesanan perperiode merupakan informasi tentang data tamu pada Hotel Telaga Biru Kota Pagaralam.

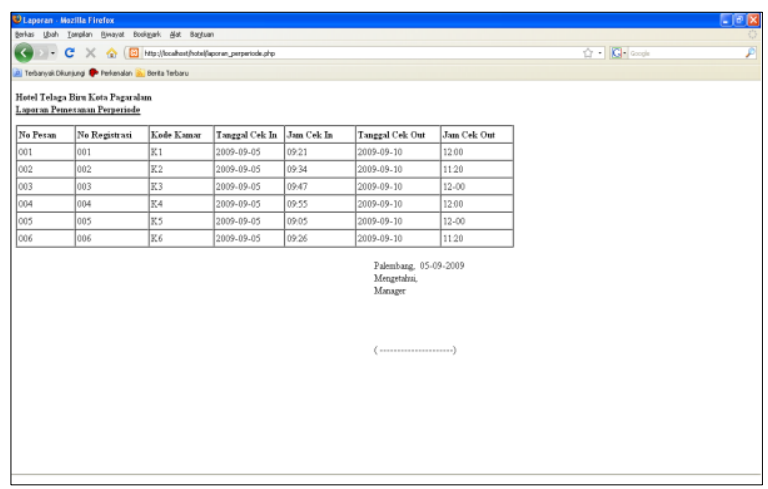

Gambar 18. Halaman Laporan Pemesanan Perperiode

\section{Halaman Lap. Pembayaran Perperiode}

Halaman laporan pembayaran perperiode merupakan informasi tentang data pembayaran pada Hotel Telaga Biru Kota Pagaralam.

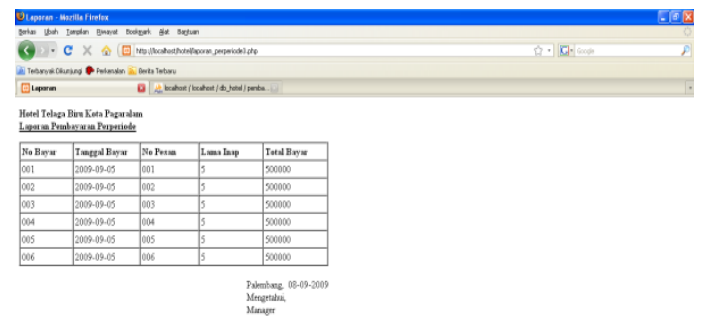

Gambar 19. Halaman Laporan Pembayaran Perperiode 


\section{KESIMPULAN}

Berdasarkan dari hasil penelitian yang telah dilakukan pada Hotel "Telaga Biru" Pagaralam, maka dapat disimpulkan bahwa dalam penelitian ini telah dihasilkan Sistem EReservation Pemesanan kamar pada hotel tersebut yang dibangun dengan metode pengembangan sistem Web Engineering. Sistem e-reservation yang dibangun memberikan kemudahan bagi konsumen untuk melakukan reservasi pada hotel karena dapat dilakukan secara online. Dengan mengimplementasikan sistem e-reservation ini dapat memberikan kemudahan dalam melakukan transaksi tanpa perlu datang langsung atau berkomunikasi langsung dengan pihak hotel. Selain itu sistem yang dibangun juga dapat menjadi media promosi bagi pihak hotel agar dapat dikenal lebih luas oleh masyarakat.

\section{DAFTAR PUSTAKA}

[1] Ruslan. "Pengelolaan Reservasi Hotel Melalui Aplikasi Berbasis Website". Jurnal Sigmata, 4(2): 28-36,2016.

[2] Sardiarinto, Sa'diyah Noor, \& Anik Andriani...'Rancang Bangun Sistem Reservasi Hotel Menggunakan Metode Waterfall”. Jurnal Bianglala Informatika,3(1): 50-57. 2015

[3] Monaghan, Kelly. "The Travel Agent's Cmplete Desk Rerence 5th Edition Traveler, Jakarta, 2009

[4] Pressman, Roger S, “Web Engineering; $A$ Practitioner's Approach". McGraw-Hill, New York.2009.

[5] Hardian Jungjungan Sitanggang, Elis Hernawati, Ferra Arik Tridalestari, "Aplikasi Reservasi Kamar Wisma Berbasis Web", e-Proceeding of Applied Science, Vol.3, No.3, 2017

[6] Samuel Eddy Gio Tatu, Andree E. Widjaja, dan Suryasari, "Pengembangan Sistem Informasi Menejemen dan Reservasi Hotel Ranaka Berbasis Web", Seminar dan Konferensi Nasional IDEC, 2019

[7] A. S., Rosa dan Shalahuddin, M.. Rekayasa Perangkat Lunak Terstruktur Dan Berorientasi Objek. Bandung: Informatika. 2013 